\title{
The Effect of Photoperiod Duration on the Dynamics of Content of Water-Soluble Carbohydrates in Soybean Seeds (Glysine max (L.) Merr.)
}

\author{
V. V. Zhmurko, *Hider Nibil Hussein Al-Hamadeni \\ V. N. Karazin Kharkiv National University, Ukraine \\ * Corresponding author. E-mail zhmurko@karazin.ua
}

Paper received 09.02.19; Accepted for publication 15.02.19.

https://doi.org/10.31174/SEND-NT2019-193VII23-05

\begin{abstract}
During field experiments, we studied the dynamics of accumulation of various forms of carbohydrates in the seeds of four varieties of cultural soybeans, which differed in the level of photoperiodic sensitivity. Plants grew under the conditions of a natural long day (16 hours at the latitude of Kharkiv City, $50^{\circ} \mathrm{N}$ ) and under the conditions of an artificial short day (9 hours). The carbohydrate content was determined at the stage of seed formation. Among all the varieties, regardless of their photoperiodic sensitivity, a short photoperiod stimulated the accumulation of carbohydrates in comparison with the accumulation in a natural long day. It is assumed that the process of formation of a set of carbohydrates in soybean seeds is subject to photoperiodic control.
\end{abstract}

Keywords: soybean, (Glysine max (L.) Merr.), photoperiod, development rates, carbohydrates.

Introduction. Soya bean is one of the most valuable food, feed and technical crops in the world [1-3,16]. The value of this crop lies in that its seeds contain a significant amount of protein, oil, biologically active substances, antioxidants [1-3,16], determining the versatile application of soybean seeds for the production of highly nutritious foods as well as animal feed. This requires high-yielding soybean varieties with a high content of primarily protein and oil in the seeds, as well as other substances that pre-determine the biological value of soybean $[1-3,9,16]$.

Different forms of carbohydrates are very important storage compounds of soybean seeds, which also stand for their nutritional value $[14,15,17]$. Reference data show that the content of different forms of carbohydrates in soybean seeds depends on environmental factors, variety genotype, as well as genotype $\times$ medium interaction.

Thus, the study of the content of oligosaccharides in the seeds of 148 soybean genotypes showed a more significant genotypic variation of the sucrose content than that of raffinose and stachyose. It is also shown that the level of sucrose content in the seven varieties studied from different geographical locations is higher in conditions with a cooler climate [13]. In experiments with vegetable soybean variety BRS 267 , it has been found that the seeds at the R6 stage had a lower sucrose content, but higher levels of starch, glucose, fructose and stachyose, than at the R8 stage [15].

It is shown that the need to improve the composition of soybean seeds to increase the sucrose content and reduce the raffinose family oligosaccharides (RFO) content. The outcomes of experiments with soybean lines that carry the raffinose synthase gene (RS2) showed that they had a similar carbohydrate profile. The authors believe that further research is required to investigate into the environmental stability of the carbohydrate profiles of soybean seeds, depending on the environmental factors [11].

The content of starch in the soybean seeds affects the taste and technological properties of soy products. In 169 recombinant inbred lines (RIL) obtained from crossing in Williams 82 and PI 366121, quantitative trait loci (QTL) for soybean starch were identified. Nine significant QTLs were identified to be used for soybean breeding $[10,16]$. Raffinose and stachyose (raffinose family oligosaccharides, RFO) are among the main antinutritional factors in soybean seeds [17]. Therefore, studies are conducted to identify genotypes with low levels of their content. With 59 soybean genotypes (19 varieties, 11 germ plasmas, and 29 breeding lines), the raffinose and stachyose content depended on the genotype of the sample studied.

When studying the content of carbohydrates in the seeds of commercial varieties and pre- commercial lines in Brazil under different growing conditions, the significant environmental impact on the level of carbohydrates of the RFO group was shown. Samples with a low and stable level of RFOs in different environmental conditions, which can be a valuable material for breeding, were isolated [14].

Thus, the data show that carbohydrates in soybean seeds are important components that determine their nutritional value. The dependence of the content of different forms of carbohydrates on environmental factors, genotype and genotype $\times$ environment interactions is shown. In addition, raffinose family oligosaccharides (RFO) are one of the anti-nutritional factors, thus setting the task of creating varieties with their low content.

When breeding such varieties, the fact should be considered that among the environmental factors, determining productivity, crop quality and plant prevalence by growing zones, the photoperiod duration is the most important [4,5]. Soybean, by its biological nature, belongs to short-day plants, which, with an increase in the photoperiod duration of up to $16-17$ hours in the daily cycle, slow down the transition to the generative state and late maturation $[4,5,12]$.

From this point of view, the initial material with low photoperiodic sensitivity should be used in breeding for high carbohydrate content in seeds. However, reference materials contain no data on the impact of the photoperiod on the process of formation of a complex of carbohydrates in soybean seeds. The effect of the photoperiod on the protein and oil content in the seeds of two soybean varieties is shown [6].

The purpose of research. With due regard to the foregoing, the task of our research included the study of the dynamics of carbohydrate accumulation in soybean seeds during their formation in photoperiodic induction. 
Materials and methods. Plant material. Four soybean varieties with different ripening terms are used in the experiments. The Annushka variety is an early ripe type with the growing season of 95-100 days; the Yatran variety is a medium early ripe type with the growing season of 100-110 days; the Ustia variety is an ultra-early ripe type with the growing season of 85-90 days. The Khadjibey variety is featured by late ripening, where the growing season is 120-130 days. The seeds of the studied varieties for conducting experiments were kindly provided by the grain legumes and cereals genetic resources laboratory of the National Center for Plant Genetic Resources of Ukraine - V. Ya. Yuriev, the National Academy of Agrarian Sciences of Ukraine.

Conditions of growing plants. Field experiments were held during the growing season of 2015-2017. on the experimental site of the Plant Physiology and Biochemistry Department, V. N. Karazin Kharkiv National University. The site is located in the territory of the Botanical Garden of the University. The soil of the plot is heavy-loam podzolized black soil.

Seeds were sowed at the optimum time for the eastern forest-steppe of Ukraine from May $10^{\text {th }}$ till May $20^{\text {th }}$, on the plots with an area of $1 \mathrm{sq}$. $\mathrm{m}$. in triplicates for each version studied.

After sprouting and before the three true leaves unfold phase, all the plants grew in the conditions of a natural long day (about 16 hours at the latitude of Kharkiv City, $50^{\circ} \mathrm{N}$ ). In the three true leaves unfold phase, a half of the plants of each variety were exposed to a short 9-hour photoperiod. To do so, they were dimmed by opaque cabins from 18:00 till 21:00 hours. The exposure to a short photoperiod continued for 14 days (photoperiodic induction). At the end of this period, the plants continued to grow in a natural long day before maturation.

Biochemical analyses. To determine the dynamics of carbohydrate accumulation in the seeds during the process of their formation, beans were picked simultaneously on a long and short day from 15-20 plants. The selection was carried out a week after the start of the formation of beans and then twice after 10 days. The material was exposed for 30 minutes at $120^{\circ} \mathrm{C}$ in a drying chamber; the beans were dried and divided into shells and seeds, the content of water-soluble carbohydrates - monosaccharides and oligosaccharides - was determined in seeds [8]. The results are processed statistically; the figures show the average and standard deviations.

Results and discussions. In our previous studies [5], it was shown that under the influence of photoperiodic induction with a short photoperiod, the varieties of Annushka, Ustia and Yatran did not show changes in the duration of the sprouting \& flowering and sprouting \& maturing period. With the Khadjibey variety, the duration of these periods was significantly reduced (by 10-15 days) under the influence of induction by a short day compared to its duration in a natural long day. Consequently, the varieties of Annushka, Yatran and Ustia are not sensitive to the duration of the photoperiod, that is, they are photoperiodically neutral. The Khadjibey variety showed high photoperiodic sensitivity, representing a short-day type of photoperiodic reaction.

As predetermined by the purpose of this paper, we studied the effect of photoperiodic induction by a short photoperiod on the accumulation of water-soluble carbohydrates in the seeds of the varieties studied in the process of their formation. The results of studying the dynamics of accumulation of monosaccharides in the seeds of the varieties studied are shown in Figure 1.

The results showed that all the studied varieties accumulated monosaccharides in the seed formation process both in plants grown under the conditions of a natural long day and those exposed to a short photoperiod (Fig. 1).

Moreover, the dynamics of the accumulation of monosaccharides in seeds depended on the photoperiodic sensitivity of the variety and the photoperiodic conditions in which the plants were grown. Thus, in the photoperiodically neutral varieties Annushka, Yatran and Ustia, saccharides began to accumulate almost simultaneously under the conditions of both a long and short photoperiod. However, in seeds of plants grown under the conditions of a short photoperiod, they accumulated more intensively, as evidenced by their greater content in each sampling period (Fig. 1).
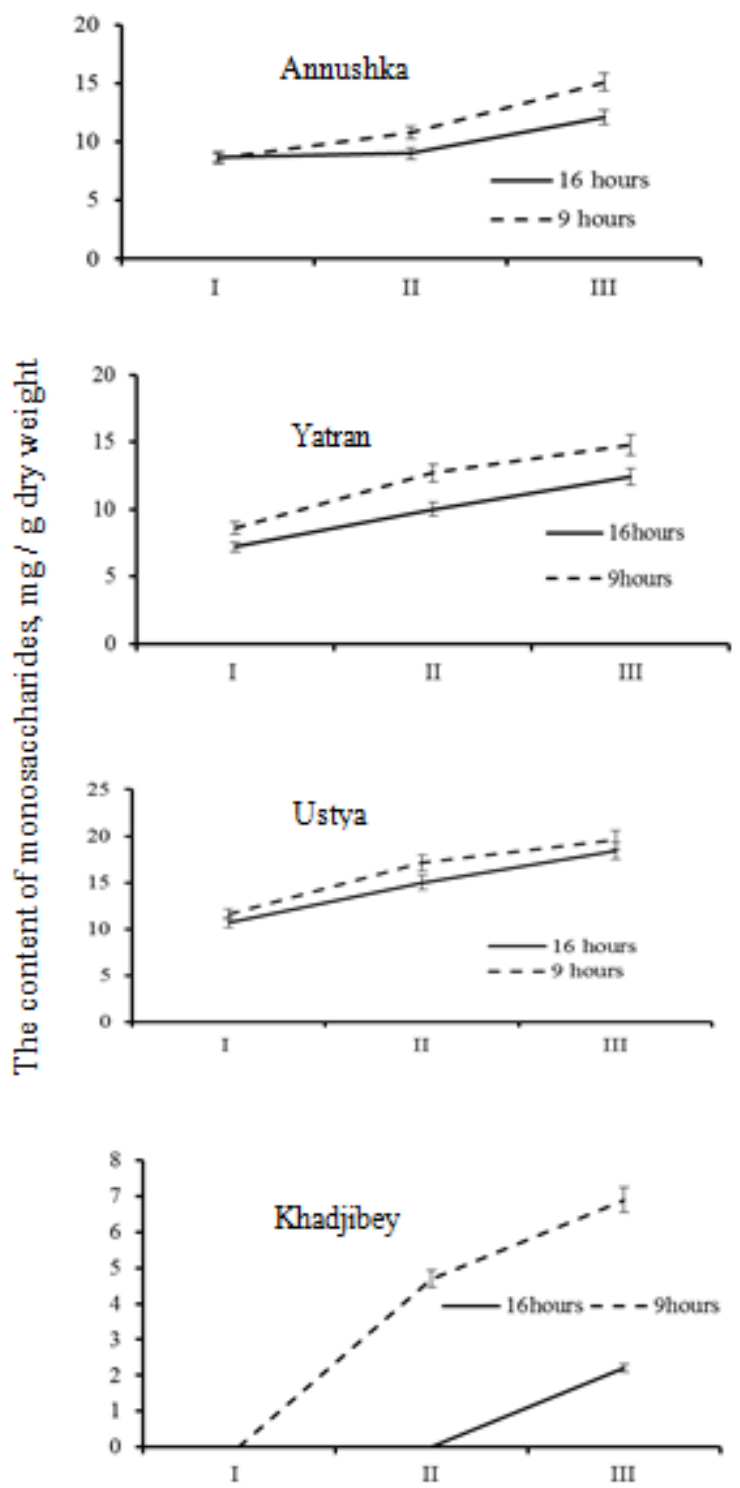

Timing of sampling

Fig. 1 The effect of the photoperiod duration on the dynamics of the content of monosaccharides in the seeds of soybean varieties in the process of formation. 

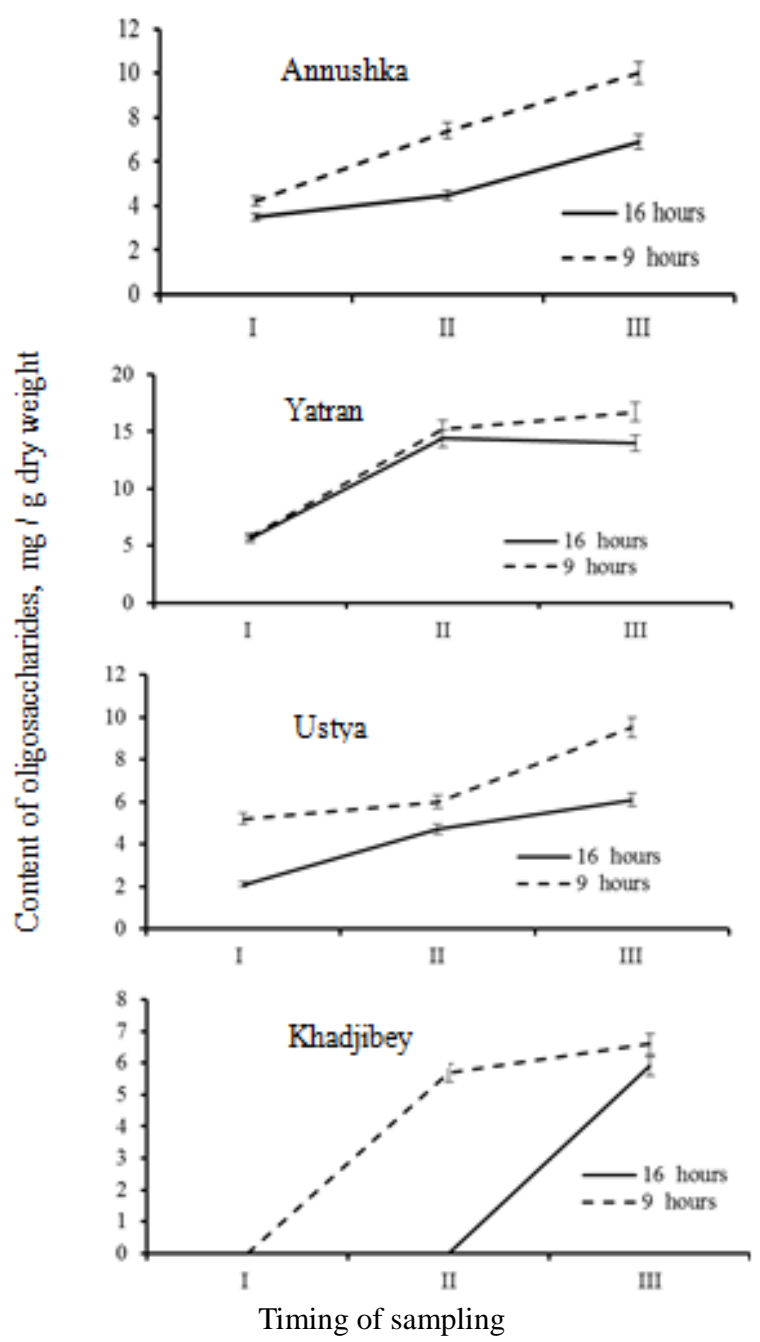

Fig. 2 The effect of the photoperiod duration on the dynamics of the content of oligosaccharides in the seeds of soybean varieties in the process of formation.

In the short-day variety Khadjibey, in contrast to the photoperiodically neutral varieties, the accumulation of monosaccharides in the seeds of plants grown with a short day began much earlier and occurred more intensively than in the seeds of plants grown under the conditions of a natural long day (Fig. 1).

We have also studied the process of accumulation of oligosaccharides by the emerging seeds of the studied soybean varieties, depending on the photoperiod duration. The results are shown in Figure 2. They evidenced that the dynamics of the content of these forms of carbohydrates was similar to that found for the accumulation of monosaccharides.
Thus, in the Annushka, Yatran and Ustia varieties, showing a neutral photoperiodic reaction, the accumulation of oligosaccharides in the seeds began almost simultaneously both in the plants grown on a long day and in the plants exposed to a short photoperiod (photoperiodic induction). In the short-day Khadjibey variety, the accumulation of oligosaccharides in the seeds of plants grown under the conditions of photoperiodic induction with a short photoperiod began much earlier than in the seeds of plants grown under conditions of a natural long day (Fig. 2). In all the varieties studied, the accumulation of oligosaccharides in the plants exposed to photoperiodic induction by a short photoperiod occurred more intensively than in the plants grown under the conditions of a natural long day.

The dynamics of the accumulation of saccharides in all varieties both in the long and short day period are similar, that is, as the seeds were formed, the carbohydrate content increased, although some fluctuation occurred. Probably, it may be explained by the genotypic characteristics of the varieties studied according to the mechanisms of formation of reserve carbohydrates in the seed.

Thus, in all the studied varieties, photoperiodic induction with a short photoperiod led to an intensification of the process of accumulation of watersoluble carbohydrates by seeds. Nevertheless, the shortday variety differed from photoperiodically neutral varieties in the intensity of the dynamics of the accumulation of carbohydrates by seeds exposed to photoperiodic induction.

In our opinion, the identified features of the accumulation of carbohydrates in soybean seeds exposed to a short photoperiod are associated with the process of accumulation and outflow of carbohydrates in the leaves of soybean plants. It is shown that with a reduction in the photoperiod, the intensity of carbohydrate accumulation in the leaves of short-day and photoperiodically neutral soybean genotypes increases in comparison with the intensity in a natural long day. In this case, the intensity of their outflow to the forming meristems increases $[4,5]$. Fruits and seeds in the process of their formation are the main artaging centers of assimilates in plants. For this reason, carbohydrates outflow to the emerging soybean seeds with a short-day photoperiodic induction under the conditions of a short photoperiod more intensively than under the conditions of a natural long day. This suggests that the process of seed formation and, in particular, the accumulation of carbohydrates in seeds in the soybean varieties studied is subject to photoperiodic regulation.

\section{ЛИТЕРАТУРА}

1. Адамовская В.Г., Молодченкова О.О., Сичкарь В.И., Картузова Т.В., Безкровная Л.Я., Лаврова Г.Д. Компонентный состав 7S и $11 \mathrm{~S}$ глобулинов сои у гибридных лини й $\mathrm{F} 6$ и их родительских форм //Фактори експериментальної еволюції організмів. 2015. Том 17. С. 280-283

2. Абугалиева А.И., Дидоренко С.В. Генетическое разнообразие сортов сои различных групп спелости по признпкам продуктивности и качества // Вавиловский журнал гнетики и селекции, 2016; 20(3):303-310

3. Вишнякова, М.А., Сеферова И.В., Самсонова М.Г. Требования к исходному материалу для селекции сои в контексте современных биотехнологий // Сельскохозяйственная биология, 2017, т.52, №5 с. 905-916

4. Жмурко В.В., Авксентьєва О.О., Юхно Ю.Ю., Попова Ю.В., Самойлов А.М., Тимошенко В.Ф., Васильченко М.С., Шулік В.В., Зубрич О.І. Ефекти генів фотоперіодичної чутливості і потреби в яровизації на фізіологобіохімічні процеси у рослин пшениці м'якої і сої культурної: Фізіологія рослин: досягнення та нові напрямки розвитку. К.: Логос, 2017. - С.187-196

5. Жмурко В.В., Хайдер Набил Хусейн Аль-Хамадени Влияние продолжительности фотопериода на формирование плодов у сортов сои (Glycine max (L.) Merr.) Фактори експериментальної еволюції організмів,2018. - Т.23. - с. 5761

6. Мысак Е. В., Селихова О. А. Изменение биохимического 
состава зерна сои в зависимости от продолжительности дня. - Сб. материалов VII-й Международной дистанционной научно-практической конференции молодых ученых. Краснодар: 2017.c.204-209

7. Молодченкова О. О., Адамовська В. Г., Січкар В. І., Картузова Т. В., Безкровна Л. Я., Лихота О. Б., Лаврова Г. Д Особливості біохімічного складу насіння сої для добору сортів продовольчого напряму//Селекція і насінництво. 2016. Випуск 110. С.150-161

8. Методы биохимического исследования растений / под ред. А. И. Ермакова. - Л.: Агропомиздат, 1987. - 430 с.

9. Choi Sang Woo, Han Sung Jin, Sung Mi Kyung, Chung Jong Il Variation of raffinose and stachiose content as influenced by genotype in soybean seed // Journal of Agriculture \& Life Science 2015 Vol.49 No.4pp.73-80

10. Dhungana Sanjeev K., Kulkarn Krishnanand P i, Park Cheo W., Jo Hyun, Song Jong T., Shin Dong-Hyun, Lee Jeong-Dong Mapping quantitative trait loci controlling soybean seed starch content in an interspecific cross of 'Williams 82' (Glycine max) and 'PI 366121'(Glycine soja)// Plant Breeding, 2017. V. 136, Issues 3. PP. 379-385

11. Hagely Katherine B., Palmquist Debra, and Kristin D. Bilyeu Classification of distinct seed carbohydrate profiles in soybean // J. Agric. Food Chem., 2013, 61 (5), pp 1105-1111

12. Kantolic Adriana G, Peralta Guillermo, Slafer Gustavo A Seed number responses to photoperiod and shading during reproductive stages in indeterminante soybean//Europien
Journal of Agronomy 2013, 51: 91-100

13. Kumar V., R a n i A., G o y a 1 L., D i x i t A.K., M a n j a y a J.G., D e v J., S w a $\mathrm{m}$ y M. Sucrose and raffinose family oligosaccharides (RFOs) in soybean seeds as influenced by genotype and growing location. J. Agric. Food Chem., 2010, 58(8): 5081-5085

14. Matei Gilvani, Woyann Leomar Guilherme, Meneguzzi Cátia, Todeschini Matheus Henrique, Trevizan Diego Maciel, Rosa Ana Claudia , Benin Giovani Profiling and genotypexenvironntment interactions of seed sugar contents in Brazilian soybean genotypes// Euphytica, 2017, 213:203

15. $\mathrm{S}$ a $\mathrm{nt}$ a $\mathrm{n}$ a A.C., $\mathrm{C}$ a r r a o- $\mathrm{P}$ a n i z z i M.C., $\mathrm{M}$ a n d a ri n o J.M.G., L e i t e R.S., S i lv a J.B., I d a E.I. Effect of harvest at different times of day on the physical and chemical characteristics of vegetable-type soybean. Ciênc. Tecnol. Aliment., 2012, 32(2): 351-356

16. Sanjeev K. Dhungana, Krishnanand P. Kulkarni, Cheol W. Park, Hyun Jo, Jong T. Song, Dong-Hyun Shin, Jeong-Dong Lee Mapping quantitative trait loci controlling soybean seed starch content in an interspecific cross of 'Williams 82' (Glycine maz) and 'PI 366121'(Glycine soja)// Plant Breeding, 2017. V. 136, Issues 3. PP. 379-385

17. Sang Woo Choi, Sung Jin Han,Mi Kyung Sung, Jong Il Chung Variation of raffinose and stachiose content as influenced by genotype in soybean seed // Journal of Agriculture \& Life Science 2015 Vol.49 No.4pp.73-80

\section{REFERENCES}

1. Adamovskaya V.G, Molodchenkova O.O., Sichkar V.I., Kartuzova T.V., Bezkrovnaya L.Y.,Lavrova G.D. A component compositions of soybean $7 \mathrm{~S}$ and $11 \mathrm{~S}$ globulins at the $\mathrm{F} 6$ hybrid lines and its parental forms // Factors in experimental evolution of organisms, 2015. V.15. PP. 280-283

2. Abugaliyeva A.I., Didorenko S.V. Genetic diversity of soybean cultivars belonging to different

ripeness groups with regard to performance and quality//Vavilov Journal of Genetics and Breeding. - 2016; 20(3):303-310 DOI $10.18699 / \mathrm{VJ} 16.168$

3. Vishnyakova M.A., Seferova I.V., Samsonova M.G.Genetic source required breeding in the context of new biotechnologies // Sel'skokhozyaistvennaya biologiya [Agricultural Biology], 2017, V. 52, N 5, pp. 905-916

4. Zhmurko VV, Avksentyeva O., Yukhno Yu.Yu., Popova Yu.V., Samoilov AM, Timoshenko V.F., Vasilchenko MS, Shulik V.V., Zubrich OI Effects of genes of photoperiodic sensitivity and need for vernalization on physiological and biochemical processes in soft wheat and soybean plants: Plant physiology: achievements and new directions of development. K.: Logos, 2017. - p.187-196

5. Zhmurko V.V., Haider Nabil Hussain Al-Hamadeni Influence of photoperiod duration on the formation of fruits in soybean varieties (Glycine $\max (\mathrm{L}$.) Merr.) // Factors in experimental evolution of organisms, 2018. V.23. PP. 57-61

6. Mysak E.V., Selichova O.A., Chenge in biochemical composition of soybean grain depending on the length of day - Collection of materials of the VII-th International distance scientific conference of young scientists. - Krasnodar: 2017. PP 204-209

7. Molodchenkova O. O., Adamovskaya V. G., Sichkar V. I., Kartuzova T. V., Bezkrovnaya L.

Ya., Likhota E. B., Lavrova G. D Bichemical characteristics of soybean seeds for selection of food varieties//Selection and seed production. 2016. Issue 110. - PP. 150-161

8. Methods of biochemical studies of plants / ed. A.I. Ermakova. - L .: Agropomizdat, 1987. - $430 \mathrm{~s}$. 